\title{
The impact of macro economy toward profitability of Islamic bank
}

\author{
Yunice Karina Tumewang ${ }^{1 *}$, Rindang Nuri Isnaini², \\ Jannatul Liutammima Musta'in ${ }^{3}$ \\ ${ }^{1}$ Department of Accounting, Faculty of Business and Economics, Universitas \\ Islam Indonesia, Yogyakarta, Indonesia \\ 2 Department of Economics, Faculty of Business and Economics, Universitas \\ Islam Indonesia, Yogyakarta, Indonesia \\ ${ }^{3}$ Department of Economics, Faculty of Economics and Business, Universitas \\ Ahmad Dahlan, Yogyakarta, Indonesia \\ *Corresponding author: yunice.karina@uii.ac.id
}

\author{
Article History \\ Received, 3 November 2019 \\ Revised 1, 20 November 2019 \\ Revised 2, 27 November 2019 \\ Accepted, 10 December 2019
}

\begin{abstract}
Purpose: The aim of this study was to examine the impact of macro economy variables such as inflation, interest rate, and exchange rate toward the profitability of Islamic bank.

Methodology: The research used quantitative approach through purposive sampling by using secondary data in the form of monthly time series from January 2015 to December 2012.

Findings: The result shows that the inflation rate does not affect the bank income. The interest rate influences bank management in determining the level of margins and profit sharing so that partners continue to use Islamic bank products. In addition, the exchange rate does not have significant effect on the income of Islamic banks.
\end{abstract}

Originality: As far as we are concerned, there are only few publications examining the effect of macro economy variable toward profitability of Islamic bank, particularly in the largest Muslim country during the period of December 2012-January 2015.

Keyword: macro economy, profitability, Islamic bank

Cite this:

Tumewang, Y.K., Isnaini, R.N., \& Musta'in, J.L. (2019). The impact of macro economy toward profitability of Islamic bank. Asian JournalofIslamicManagement,1(2), 101-108. DOI: 10.1108/AJIM.vol1.iss2.art4

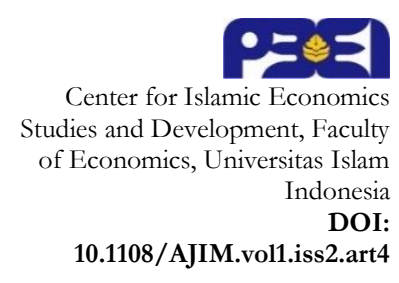

\section{Introduction}

The level of return on assets shows the ability of bank management to generate income from the use of assets owned. Islamic bank assets are usually utilized in the form of financing. Funding is widely offered by bank management in the form of financing for sale and purchase with murabaha, istisna and salam schemes. The other financing are in the form of profit sharing in the form of mudharabah, musyrakah and mudharabah. Apart from Islamic bank financing, there is also a source of income from SBIS, secondary markets and bank services. While external factors that affect income include inflation, interest rates and exchange rates.

Previous studies have shown the role of inflation, interest rates and exchange rates, including the research conducted by Masood. B and Ashraf. M (2012) empirically investigates the impact of macroeconomic and bank specific variables on the profitability of Islamic banks. 
Research variables include bank internal factors such as asset quality, asset size, liquidity, deposits, gearing operating efficiency ratios. In addition to that, it includes macroeconomic variables such as real GDP growth rates and annual inflation. The result shows that efficient management in the impact of their operating costs was significantly positive on the profitability of Islamic banks.

Sudarsono (2017) examines the factors that influence the profitability (ROA) of Islamic banking in Indonesia. The data used monthly data from Islamic bank financial statements for the period 20102015. The results of the data processing show that FIN and BOPO are positively related to ROA, while DPK, TBH, FDR have a negative relationship with ROA and SBIS and NPF have no effect on ROA level. On the other hand, financing responses to shocks that occur in ROA, FIN, FDR, NPF and BOPO are responded positively by ROA. While the ROA response to shocks that occur in FDR, SBIS and TBH is negative.

Idris et. al (2011) investigated the profitability of Islamic banks in Malaysia by including several internal factors such as liquidity, credit risk of bank size, capital adequacy, and expenditure. The results showed that only the size of the bank is a significant and positive determinant of the profitability of Islamic banks.

Ubaidilah (2016) examines the effects of Capital Adequacy Ratio (CAR), Financing to Deposit Ratio (FDR), Non Performing Financing (NPF), Preparation of Eliminating Earning Assets (PPAP), Operational Costs per Operating Income (BOPO), Share of Financing, Bank Indonesia Sharia Certificate (SBIS). The results of this study indicate that the NPF, PPAP, and SBIS variables do not show a significant effect on profitability. The FDR variable shows a significant positive effect on profitability, while the CAR, BOPO, and Financing Share variables have a negative and significant effect on profitability.

Grassa, R. (2012) examines the relationship between risk and income structure of Islamic banks from GCC countries by using data from 42 Islamic banks during period of 2002-2008. The results show that registered and unregistered Islamic banks are associated with higher insolvency risk and greater risk for profit sharing products and loss of trust. This study did not find a relationship between the level of risk and non-profit operating income sharing losses, therefore the registered banks prefer to invest in non-profit sharing sharing products in contrast to profitsharing and loss products.

Wasiuzzaman, A. and Gunasegavan, U.N. (2013) conducted a comparative study on the performance of 14 conventional and Islamic banks in Malaysia during the period of 2005 to 2009. They have used multiple regression analysis and independent sample $\mathrm{t}$-test. The findings show that returns to bank size, average assets and board size of non-Islamic banks are greater than those of Islamic banks. The study also found significant comparisons between other variables from research in Islamic and non-Islamic banks except for board independence and profitability.

Ali et.al (2011) empirically investigated the relationship between macroeconomic indicators and bank specific variables on profitability in Pakistani commercial banks using data during the period from 2006 to 2009. The results of the study suggest that a good economic environment and efficient management in the asset side has a significant impact on profitability. On the other hand, lower profitability is found in high credit risk and capitalization. It was concluded that the higher the operating efficiency, the higher the profitability.

Cevik, S. and Charap, J. (2011) examined returns on Islamic and conventional bank deposits in Indonesia, Turkey, and Malaysia. Research findings suggest that there is a long-term integration between PLS returns and conventional bank deposit rates. However, it was also found that conventional bank deposit rates cause a return on PLS accounts.

Ahokpossi, C. (2013), empirically investigated the determinants of bank interest margins in the Sub-Saharan African countries by using unbalanced panel data from 41 SSA countries with 456 banks over the period 1995 to 2008. They have applied a random effects model. The findings suggest that bank specific factors (bank equity, liquidity risk and credit risk) are the main determinants of interest margins. On the other hand, interest margin and inflation are sensitive to each other. This sensitivity is not for economic and public growth, but for foreign ownership. 


\section{Literature Review and Hypotheses Development}

\section{Inflation toward Profitability}

Abduh et.al (2011) empirically analyzed macroeconomic variables and crisis management on Islamic bank deposits in Malaysia using monthly time series data for the period 2000 to 2010. The findings show that GDP, interest rates and changes in profit levels had no impact on Islamic banks while inflation shows a negative relationship with Islamic banks. On the other hand, the financial crisis is positively related to Islamic banks.

Meanwhile, other exisiting literature such as Haffernan Fu (2008), Bashir (2000), Teacher et.al (2002), Athanasoglou et al. (2005) and Vong and Hoi (2009) found a positive relationship between Islamic bank profits and the prevailing inflation rate in this country. This relationship shows that the income of Islamic banks increases more than costs with an inflation rate. Therefore, it is hypothesed as follows:

H1: Inflation rate has a significant positive effect on the profitability of Islamic bank

\section{Interest Rate toward Profitability}

Kasri and Kassim (2009) investigated thatfactors affecting savings of Islamic banks in Indonesia using Vector auto regressive and related to the responsive function of Impulse methodology for all Islamic Banks in Indonesia from 2000 to 2007. Variable real rate of return on sharia savings, interest rates conventional deposits, real income, and number of Islamic bank branches are considered. The results show that the profit rate has a strong positive relationship with Islamic bank deposits, while interest rates have a strong negative relationship with it.

Adebola et.al, (2011) empirically investigated Islamic bank financing and macroeconomic relationship variables in Malaysia using data from 2006 to 2011. They have implemented the ARDL test for joint integration and the Granger causality test. The results showed that Islamic bank financing was significantly affected by the interest rate in Malaysia. On the other hand they also found a long-term relationship between the research variables.

Huapea, A.G. and Kasri, R.A., (2010), investigating bank margins by comparing Islamic banks and conventional banks. Data was collected for 5 banks from 1996 to 2006 and the ARDL Model was applied to test integration between variables. The findings suggest for the long term the association exists between bank margins and determinants of Islamic banks. On the other hand, interest rate volatility negatively impacts the margins of Islamic banks while conventional banks respond positively. Therefore, it is hypotheses as follows:

H2: Interest rate has a significant positive effect on the profitability of Islamic bank

\section{Exchange Rate toward Profitability}

The exchange rate measures the relative value of a country's currency against the value of the currency of its trading partners. Mbutor (2010) studies the relationship between lending bank lending, exchange rate volatility and stock price fluctuation. The study suggests that exchange rate fluctuations affect the lending behavior of Nigerian banks, however the effects were insignificant. Mansur and Elyasiani (1995) found that exchange rate have no direct effect on bank lending however it seems to affect bank financing activities through its effect on real output and stock prices. Similarly, Adebola et al. (2011) also confirmed the same findings that there is an association between real effective exchange rate and Islamic bank financing, however the relationship is insignificant in long run. Mansur and Elyasiani (1995) found that exchange rate volatility have no direct impact on bank lending however it seems to affect bank financing activities through its effect on real output and stock prices. Therefore, it is hypotheses as follows:

H3: Exchange rate has a significant positive effect on the profitability of Islamic bank 


\section{Research Frameworks and Hypothesis}

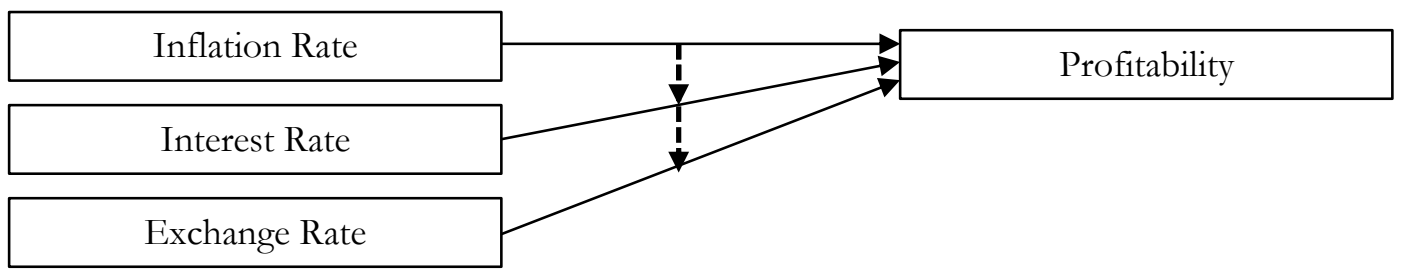

Figure 1. Theoretical Frameworks

\section{Methods}

\section{Type of Research}

This research is classified as a causal research. The purpose of this research is to examine the effect of macro economy toward the profitability of Islamic bank. This research used quantitative approach. The approach was seen as having objective observations, precise measurements, statistical analysis and verifiable truths. The secondary data collection methods were used in this research. The secondary data was collected from the Financial Services Authority $(\mathrm{OJK})$ and the Central Bureau of Statistics (BPS) in the form of monthly time series from January 2015 to December 2012. The data used are Return on Assets (ROA), inflation rate (INFLATION), interest rate (BIRATE) and rupiah exchange rate (EXRATE)

Unit root test is the most popular test to find out the stationary of a data. Then, to test the unit roots in this study an Augmented Dickey-Fuller (ADF) test was used. OLS regression model to determine the factors that most influence the dependent variable is also the importance of the independent variable with the dependent variable. Granger causality test is used to check the cause and effect direction of the variable and finally the stability analysis is carried out using CUSUM and CUSUM square.

The equation in this study is as follows:

ROA $=\alpha+\beta_{1}$ INFLATION $+\beta_{2}$ BIRATE $+\beta_{3}$ EXRATE $+\varepsilon t$

Where ROA is the profitability of Islamic bank, INFLATION is the inflation rate, BIRATE is the rate of BI interest, and EXRATE is the exchange rate. st is defined as error time.

\section{Results and Discussion}

\section{Unit Square Test}

Data stationarity test is an important step in analyzing time series data. Unit root test results at the level can be seen in Table 2. The results of the stationarity test data at the level shows that all variables are not stationary at $5 \%$ significance level. This is because the absolute value of $\mathrm{t}-\mathrm{ADF}$ is smaller than the absolute value of MacKinnon Critical Values at the level of 5\%. Research with non-stationary data can produce spurious regression. Therefore, the stationarity test is continued at the first difference level. Which shows that all data used in the study were stationary at the first difference level. This is because the absolute value of $\mathrm{t}-\mathrm{ADF}$ is greater than the absolute value of MacKinnon Critical Values at 5\% real level.

Table 1. Unit Square Test

\begin{tabular}{llclc}
\hline & \multicolumn{3}{c}{ Level } & First Different \\
\cline { 2 - 5 } & t-statT & Prob & t-stat & Prob \\
\hline ROA & -2.021535 & 0.2769 & -8.649332 & 0.0000 \\
INFLATION & -1.831115 & 0.3613 & -5.564679 & 0.0000 \\
BIRATE & -1.557290 & 0.4962 & -4.923167 & 0.0002 \\
EXRATE & -2.076501 & 0.2548 & -8.299930 & 0.0000 \\
\hline
\end{tabular}




\section{Cointegration Analysis}

Cointegration test aims to determine whether the variables are not stationary cointegrated or not. Cointegration testing in this study uses the Johansen Cointegration Test. All variables have been stationary at the first difference level and therefore the cointegration test through the Johansen Cointegration Test can be done. If Trace statistics> Critical Value, then the equation is cointegrated. Thus $\mathrm{HO}=$ non-cointegration with the alternative hypothesis $\mathrm{H} 1=$ cointegration. If Trace Statistics $>$ Critical Value, then reject H0 or accept H1, which means cointegration occurs.

Table 2. Result of Cointegration Test

\begin{tabular}{lcllc}
\hline Hypothesized No. of CE(s) & Eigenvalue & Trace Statistic & 0.05 Critical Value & Prob.** \\
\hline None & 0.320014 & 4.472 .281 & 4.785 .613 & 0.0956 \\
At most 1 & 0.306555 & 2.698 .140 & 2.979 .707 & 0.1021 \\
At most 2 & 0.141801 & 1.014 .156 & 1.549 .471 & 0.2700 \\
At most 3 & 0.065319 & 3.107 .284 & 3.841 .466 & 0.0779 \\
\hline
\end{tabular}

The test results in table 2 show that there are no equations in this study that are cointegrated at the $5 \%$ level. This can be seen when the value of Trace statistics $>$ Critical Value.

\section{Regression Test}

From Table 4.3, the results show that inflation has a positive and significant impact on profits made by Islamic banks in Pakistan. These results are consistent with previous studies such as Haffernan Fu (2008), Bashir (2000), Teacher et.al (2002), Athanasoglou et al. (2005) and Vong and Hoi (2009) found a positive relationship between Islamic bank profits and the prevailing inflation rate in this country. This relationship shows that the income of Islamic banks increases more than costs with an inflation rate. However, changes in the inflation rate let bank forecasts interest earned by correctly adjusting rates and margins that help Islamic banks to increase their profits. Interest rates have a positive and significant effect on Islamic bank earnings. This positive relationship is consistent with Hasan and Bashir (2003), Bourke (1989) and Molyneux and Thornton (1992). This shows the fact that interest is used as a benchmark in setting their fees for their depositors using funds and gifts given to their depositors as well (Nienhaus 1983).

Table 3. Regression Result

\begin{tabular}{lllll}
\hline Variable & Coefficient & Std. Error & t-Statistic & Prob. \\
\hline C & -2.108 .772 & 1.032 .335 & -2.042 .720 & 0.0471 \\
INFLATION & -0.003373 & 0.041123 & -0.082018 & 0.9350 \\
BIRATE & -0.086517 & 0.044022 & -1.965 .330 & 0.0557 \\
EXRATE & 0.000255 & $7.42 E-05$ & 3.438 .115 & 0.0013 \\
\hline R-squared & 0.349473 & Mean dependent var & 0.846875 \\
Adjusted R-squared & 0.305119 & S.D. dependent var & 0.319469 \\
S.E. of regression & 0.266307 & Akaike info criterion & 0.271325 \\
Sum squared resid & 3.120 .466 & Schwarz criterion & 0.427259 \\
Log likelihood & -2.511 .802 & Hannan-Quinn criter. & 0.330253 \\
F-statistic & 7.879 .172 & Durbin-Watson stat & 0.766300 \\
Prob(F-statistic) & 0.000258 & & \\
\hline
\end{tabular}

\section{Causality Analysis}

Granger causality test is used to see the causal relationship between variables in the model. This test is based on a 5\% significance level with the initial hypothesis ( $\mathrm{H} 0)$ that a variable has no causal relationship to other variables and the alternative hypothesis (H1) that a variable has a causal relationship to other variables. If the probability value is less than the real level of $5 \%$ then reject $\mathrm{H} 0$. 
Table 4. Causality Test

\begin{tabular}{lll}
\hline Null Hypothesis: & F-Statistic & Prob. \\
\hline INFLATION does not Cause ROA & 221.455 & 0.1221 \\
ROA does not Cause INFLATION & 0.12717 & 0.8809 \\
BIRATE does not Cause ROA & 203.127 & 0.1442 \\
ROA does not Cause BIRATE & 123.514 & 0.3014 \\
EXRATE does not Cause ROA & 132.602 & 0.2767 \\
ROA does not Cause EXRATE & 0.83426 & 0.4414 \\
BIRATE does not Cause INFLATION & 0.17866 & 0.8370 \\
INFLATION does not Cause BIRATE & 168.551 & 0.1979 \\
EXRATE does not Cause INFLATION & 145.845 & 0.2444 \\
INFLATION does not Cause EXRATE & 0.46503 & 0.6314 \\
EXRATE does not Cause BIRATE & 182.857 & 0.1735 \\
BIRATE does not Cause EXRATE & 366.410 & 0.0344 \\
\hline
\end{tabular}

Granger causality test results are summarized in Table 4. The results of this test indicate that BIRATE with EXRATE has a one-way relationship where BIRATE affects the EXCHANGE. On the other hand ROA with INFLATION, BIRATE and EXRATE does not have a one-way or two-way relationship.

\section{Stability Analysis}

Consistency and stability in a relationship are needed for the effectiveness of Islamic bank policies and macroeconomic variables. Therefore CUSUM and CUSU recursive square residues are applied to test the consistency of estimates over the time period under consideration. Figure 1 shows the stability test which implies that the CUSUM test results show the estimation is within two standard deviations but the CUSUM of the squared test reflects that there was a slight fluctuation in 2015 and 2018 but after that it showed stability during the study period.
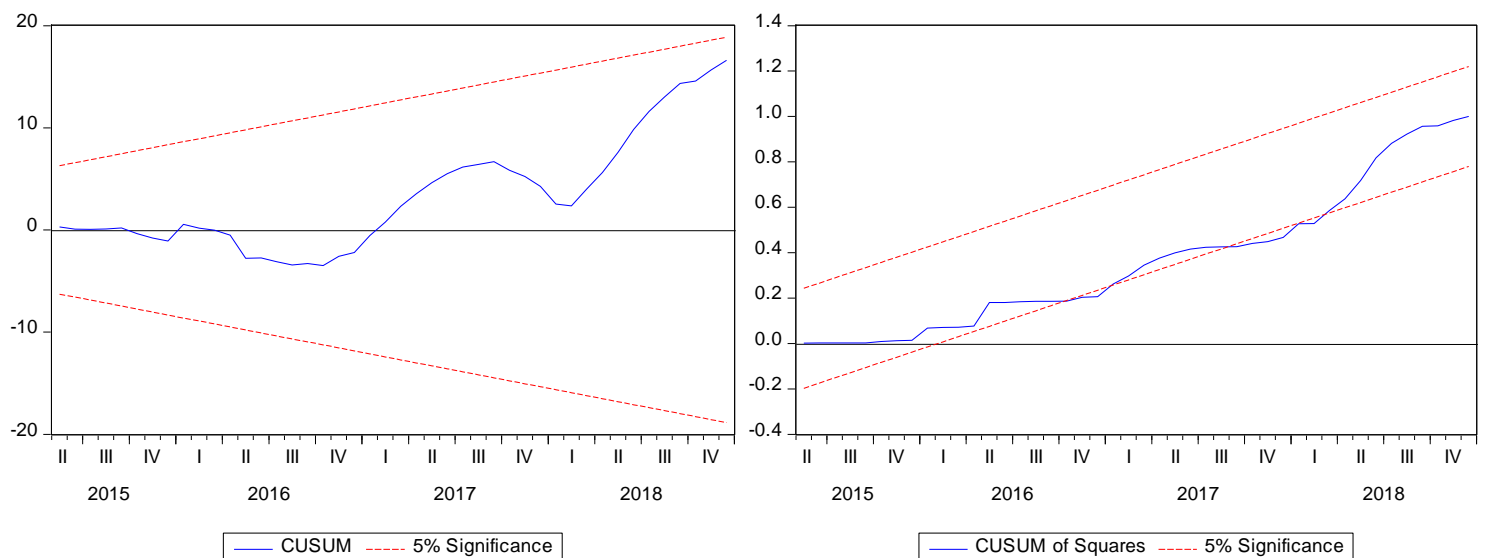

Figure 1. Stability Analysis

\section{Discussions}

\section{The influence of inflation toward profitability}

The finding show that the inflation rate does not negatively affect the level of income with a value of verification above $\alpha=93 \%$. The level of inflation does not affect bank management to make policies that are different from previous policies. This situation is caused by Islamic bank income consistent in the study period between2015-2018. In addition, the inflation rate tends to moderate less than 5\% after 2015 does not affect the decline in purchasing power. This situation makes the level of production of Islamic bank partner companies relatively stable or there is no 
significant increase or decrease. Theoretically the results of this study are in accordance with pure Islamic economic theory which explains that money functions as a medium of exchange rather than a commodity that can be traded. The implication in the Islamic economy is the amount of money in circulation reflects the transaction of goods and services in the real sector. When the money supply is high which is the cause of inflation, it actually reflects the increase in transactions of goods and services in the real sector. Thus the occurrence of inflation has no effect or impact on bank profitability (Rofiqo \& Afrianti, 2019).

\section{The influence of interest rate toward profitability}

The interest rate has a negative effect on bank income with a verification value of $0,10 \%$. The management of sharia banks in determining the margin level or ratio level for results must consider the amount of interest in conventional banks. This policy is needed to maintain the liquidity of Islamic banks, because when interest rates are high, liquidity tends to decrease and vice versa. Low liquidity causes the ability of Islamic banks to channel financing down. The decline in the ability of Islamic banks to channel funds will affect income. From the results of data processing, it shows that the management of Islamic banks is able to manage the level of margin and profit sharing when interest rates rise so that Islamic banks are able to generate income. This result is in line with (Ben Naceur, 2003; Bourke, 1989; Mohamad et al., 2019) which revealed that when there is a policy of increasing interest rates, it will increase the cost of capital so that demand for financing is low, including in Islamic banks. When there is a reduction in demand for financing it will reduce bank profitability.

\section{The influence of exchange rate toward profitability}

The exchange rate of rupiah against the dollar has a positive effect in nominal terms but negatively in real terms to the income of Islamic banks. The results of data processing can be interpreted that an increase in the value of rupiah will cause a decrease in income of Islamic banks. The fall in the value of rupiah will reduce the ability of rupiah to be used to buy goods because the price of goods becomes relatively higher. If sharia bank partner need raw materials from imports for its production, the costs incurred by entrepreneurs will be higher because the price of raw materials is relatively more expensive. This situation can be seen from the coefficient of the exchange rate to income which is relatively low, 0,000255 or although a fall in the exchange rate increases bank income but the magnitude of the change is very low. This influence can also be interpreted as sharia bank partner entrepreneurs exporting more than importing. This is in accordance with the character of entrepreneurs of Islamic bank partners, which are mostly SMEs.

\section{Conclusions}

From the results of data processing, it shows that the inflation rate does not affect the bank income. This fact is due to inflation being a major factor for the management of Islamic banks to determine the level of margins and profit sharing in order to generate revenue. On the other hand, the interest rate influences bank management in determining the level of margins and profit sharing so that partners continue to use Islamic bank products. In addition, the exchange rate does not have significant effect on the income of Islamic banks. This situation shows that the business partners of Islamic banks are mostly SMEs (Small Medium Enterprises) who sell more goods abroad.

\section{References}

Abduh, M., Omar, M.A. and Duasa,J. (2011), The Impact of Crisis and Macroeconomic Variables towards Islamic Banking Deposits, American Journal of Applied Sciences, 8 (12), 1413-1418

Adebola, S.S., Yusoff, W.S.W. and Dahalan, J. (2011), The impact of macroeconomic variables on 
Islamic banks financing in Malaysia, Research Journal of Finance and Accounting, 2 (4), 22-33.

Ahokpossi, C. (2013), Determinants of Bank Interest Margins in Sub-Saharan Africa, International Monetary Fund working paper, 1-20

Ali, K., Akhter, M.F. and Ahmed, H.Z., (2011), Bank-Specific and Macroeconomic Indicators of Profitability - Empirical Evidence from the Commercial Banks of Pakistan, International Journal of Business and Social Science, 2 (6), 235-242

Cevik S. and Charap, J. (2011), The Behavior of Conventional and Islamic Bank Deposit Returns in Malaysia and Turkey, International Monetary Fund working paper, 1-23

Grassa, R. (2012), Islamic banks' income structure and risk: evidence from GCC countries, Accounting Research Journal, 25 (3), 227-241

Huapea, A.G. and Kasri, R.A., (2010), Bank margin determination: a comparison between Islamic and conventional banks in Indonesia, International Journal of Islamic and Middle Eastern Finance and Management, Vol. 3 (1), 65-82

Idris, R.A., Asri, F.F.A.H., Taufik, N.A.A., Salim, N.J., Mustafa, R and Jusoff, K., (2011), "Determinant of Islamic Banking Institutions' Profitability in Malaysia", World applied science journal, ISSN 1818-4952, 1-7

Kasri, R.A and Kassim, S.H, (2010), Empirical Determinants of Saving in the Islamic Banks: Evidence from Indonesia, JKAU: Islamic Econ., Vol. 22, (2), 181-201

Mansur, E. Elyasiani. (1995), „, Sensitivity of bank equity returns to the level and volatility of interest rates ${ }^{\text {ee }}$ Managerial Finance, pp. 58-77

Masood, O and Ashraf, M, (2012), Bank-specific and macroeconomic profitability determinants of Islamic banks, Qualitative Research in Financial Markets, Vol. 4 (23), 255-268

Mbutor, M. (2010), “Exchange Rate Volatility, Stock Price Fluctuations and the Lending Behavior of Banks in Nigeria" Journal of Economics and International Finance, 2(11), $251-260$

Ben Naceur, S. (2003). The Determinants of the Tunisian Banking Industry Profitability: Panel Evidence. Applied Financial Economics, 11, 317-319.

Bourke, P. (1989). Concentration and other determinants of bank profitability in Europe, North America and Australia. Journal of Banking \& Finance, 65-79.

Mohamad, M. T., Sulaiman@Mohamad, A. A., Khairul Hamimah, \& Muslim, N. (2019). The Determinants of Bank Profitability: How Malaysian Islamic Banks Response to the Financing Risk. Advances in Social Sciences Research Journal, 6(12), 1-15. https://doi.org/10.14738/assri.612.7471

Rofiqo, A., \& Afrianti, N. (2019). the Influence of Sharia Banking Characteristics and Macroeconomics Factors on Sharia Banking Profitability: Empirical Studies in Indonesia. International Journal of Islamic Business Ethics, 4(1), 540. https://doi.org/10.30659/ijibe.4.1.540-550

Sudarsono, H (2017)Analisis pengaruhi kinerja keuangan terhadap profitabilitas bank syariah di Indonesia, Economica, Jurnal Ekonomi Islam, 8(2), 175-203

Ubadillah (2016), Analisis faktor-faktor yang mempengaruhi proditabilas bank syariah di Indonesia, El Jizya, Jurnal Ekonomi Islam, 4(1), 151-188

Wasiuzzaman, A. and Gunasegavan, U.N. (2013), Comparative study of the performance of Islamic and conventional banks the case of Malaysia, Humanomics, Vol. 29 (1,) 43-60. 